\title{
Miten sujuu johtaminen etänä?
}

Alankomaista alkunsa saanut, kotihoitoa tarjoava Stichting Buurtzorg on siitä erityinen organisaatio, ettei siellä ole johtajia. Vuonna 2006 perustetussa ja kymmeniin maihin laajentuneessa organisaatiossa työ on organisoitu tiimeille, jotka päättävät itse omista menettelytavoistaan ja tekevät mahdollisimman paljon itse. Toki tiimeillä on yhteisiä valmentajia, jotka auttavat tiimejä toiminnassaan. Lisäksi organisaation pääkonttori huolehtii taloushallinnosta. Stichting Buurtzorgin työntekijät ja asiakkaat ovat erittäin tyytyväisiä toimintaan, ja organisaatio on palkittu moneen kertaan. Stichting Buurtzorg on erinomainen esimerkki siitä, että työn voi organisoida perinteisestä poikkeavalla tavalla ja saada sen sujumaan. Se on muistutus myös siitä, että usein työntekijät ovat luotettavia, oman työnsä parhaita asiantuntijoita, eivätkä he anna parastaan vain siksi, että johtajat sitä heiltä edellyttävät.

Koronaviruksen mukanaan tuoma erityistilanne ja etenkin etätöihin siirtyminen on asettanut johtamisen uuteen tilanteeseen monilla työpaikoilla. Etätöihin siirryttiin nopeasti työnantajan määräyksellä. Kaikilla johtajilla ei kuitenkaan ollut aiempaa kokemusta eikä tietoa siitä, miten johdetaan etänä. Toki johtajan roolin painopiste on viime aikoina muuttunut alaisten valvonnasta heidän tukemiseensa ja valmentamiseensa, mikä varmasti onnistuu myös erilaisten teknologisten välineiden avulla. Lisäksi monilta työntekijöiltä odotetaan yhä enemmän itsensä johtamista, kuten
Stichting Buurtzorgin varsin onnistunut esimerkki osoittaa. Johtaminen on yksi mutta ei suinkaan ainoa asia, josta kaipaamme lisää tutkimustietoa näinä erityisinä aikoina.

Etätyö edellyttää luottamusta, ja juuri luottamuksen puute on ollut yksi etätyön laajentumista hidastava seikka koronaa edeltävänä aikana. Ei vielä tarkkaan tiedetä, mitä tapahtui luottamukselle, kun etätyöhön siirryttiin laajasti olosuhteiden pakosta. Muutos oli merkittävä sellaisilla työpaikoilla, joilla etätyö ei ollut aiemmin vakiintunut käytäntö tai sitä sai tehdä työnantajan luvalla vain muutamana päivänä kuukaudessa. Nähtäväksi myös jää, millaiseksi lähi- ja etätyön tekemisen suhde sekä luottamus muovautuvat, kun koronapandemia alkaa hellittää otettaan.

Työelämän tutkimus -lehteä ilmestyy tavallisesti kolme numeroa vuodessa sekä lisäksi mahdollinen teemanumero. Tästä poiketen käsissäsi on ikään kuin ylimääräinen, vuosikerran neljäs perusnumero. Reilu työ -aiheinen teemanumero ilmestyy vuoden 2021 alussa, ja sen lisäksi ensi vuonna ilmestyy suunnitelman mukaan toinenkin teemanumero. Näin ollen perusnumeroita ilmestyy vain kaksi.

Edellisessä numerossa julkaistut työelämäaiheisten opintokokonaisuuksien esittelyt poikivat vielä yhden, Turun yliopiston monitieteisen Työelämän ja henkilöstöasioiden TYHEopintokokonaisuuden esittelyn. Siitä voi lukea 
tästä numerosta. Olemme edelleen kiinnostuneita kuulemaan työelämäasioiden vakiintuneista opetussisällöistä eri oppilaitoksissa.

Kiitämme lämpimästi kautensa päättänyttä lehden toimitussihteeriä Tiina Sihtoa hänen panoksestaan lehden tekemiseen sekä kollegiaalisesta avusta ja työtoveruudesta. Toivotamme onnea ja menestystä kaikissa tulevissa tehtävissä. Samalla toivotamme sydämellisesti tervetulleeksi joukkoomme lehden uuden toimitussihteerin Heli Ilolan, jonka työ on alkanut jo tästä, käsillä olevasta numerosta.

\section{$* * *$}

Lehden ensimmäisessä artikkelissa Jaana-Piia Mäkiniemi kertoo, mitä on ohjattu elokuvien katselu, ja pohtii, miten sitä voisi käyttää työhyvinvoinnin kehittämiseen. Hän erittelee kirjallisuuskatsauksen perusteella, miten menetelmää on käytetty, ja jatkaa pohtimalla ohjatun elokuvien katselun mahdollisuuksia työhyvinvoinnin parantamisessa. Mahdollisuuksia voisi olla ihmissuhde- ja vuorovaikutustaitojen, yksilöllisten voimavarojen ja johtamistaitojen kehittämisessä. Mäkiniemi ehdottaa, että menetelmän soveltuvuutta ja vaikuttavuutta työhyvinvoinnin edistämisessä voitaisiin lisätä laadukkaalla elokuvan katselun ohjauksella sekä suunnittelemalla menetelmän käyttöprosessi huolella kohdeyleisön ja -organisaation erityispiirteet huomioiden.

Minna Toivanen kysyy, mistä syntyvät onnekkaat asiantuntijalöydöt. Hän hyödyntää serendipisyyden käsitettä, jolla tarkoitetaan yksilön kohtaamaa yllättävää, sattuman ja viisauden tai ammattitaidon ohjaamaa hyödyllistä havaintoa, ideaa, tietoa, esinettä tai ilmiötä. Serendipisyyskokemuksessa yksilö kohtaa jotakin, mitä hän ei ollut etsimässä, mutta joka on arvokasta. Hän selvittää kyselyaineiston avulla, kuinka yleisiä serendipisyyskokemukset ovat asiantuntijatyössä, missä onnekkaita löytöjä tehdään sekä missä määrin ne liittyvät yksilön omaan toimintatapaan ja missä määrin taas ulkoiseen toimintaympäristöön. Tulosten mukaan asiantuntijoista hieman yli puolet oli kohdannut onnekkaita löytöjä työssään melko tai hyvin usein, naiset useammin kuin miehet. Niillä, jotka tekivät paljon yhteistyötä, serendipisyyskokemukset olivat yleisempiä kuin muilla.

Tuulikki Ukkonen-Mikkola, Raija Yliniemi ja Outi Wallin käsittelevät varhaiskasvatuksen asiantuntijuuden uudelleenmäärittelyä. Varhaiskasvatuksen lapsiryhmissä on uuden lain mukaisesti lisätty korkeakoulutettujen työntekijöiden määrää. Lapsiryhmissä paikalla olevat ammattiryhmät ovat opettajat, sosionomit sekä lastenhoitajat. Artikkelissa kerrotaan toimintatutkimuksesta, jossa selvitettiin työntekijöiden käsityksiä omasta asiantuntijaroolistaan ja selkiytettiin eri ammattiryhmien asiantuntijuutta. Tutkimuksen mukaan moniammatilliset tiimit yhdessä tuottivat työstään voimattomuuden, kehittämisen ja lapsen edun diskurssit. Erikseen ammattiryhmät positioituivat toisistaan hieman poikkeavasti. Esimerkiksi uusin ja siten paikkaansa etsivä ryhmä, sosionomit, kuvasivat itsensä selkeimmin jaettuun vastuuseen tiimin toiminnan organisoinnista.

Jukka Niemelän, Leena Koivusillan, Noora Elosen ja Antti Saloniemen tutkimuksen kohteena on aktiivisten työvoimapoliittisten toimenpiteiden vaikutus pitkään työtä vailla olleiden ihmisten hyvinvointiin. Kyselyaineiston perusteella he toteavat, että aktiivisen työvoimapolitiikan tavanomaisilla toimenpiteillä näyttää olevan suotuisia vaikutuksia hyvinvointiin juuri niiden ihmisten keskuudessa, joilla hyvinvoinnin vajeet ovat ilmeisimmät ennen kyseessä olevaa toimenpidettä. Lisäksi tuloksissa korostuu toimenpiteiden laadun merkitys. Myönteisiä hyvinvointivaikutuksia näyttää olevan nimenomaan toimenpiteillä, joita osallistujat pitivät omassa elämäntilanteessaan mielekkäinä, itseluottamusta parantavina sekä omaa elämäntilannetta, taloudellista tilannetta ja muodollista pätevyyttä kohentavina.

Antoisia lukuhetkiä lehden parissa! 